\title{
LIBERDADE, LEI NATURAL E DIREITO NATURAL EM HOBBES: LIMIAR DO DIREITO E DA POLÍTICA NA MODERNIDADE
}

\author{
Natalia MARUYAMA ${ }^{1}$
}

- RESUMO: Liberdade e poder são dois temas que se correlacionam ao longo da história da filosofia política moderna. Nos textos de Hobbes, a ideia da liberdade como ausência de impedimentos às ações ajuda-nos a pensar o dever de obediência ao poder soberano e as relações entre política e direito. Uma situação de vácuo jurídico, em que tudo é permitido, faz-se, contudo, impossível, de modo que a solução de Hobbes consiste em sustentar a ideia do direito natural como direito originário individual vinculado à preservação da vida. Suas ideias do direito natural e da lei natural, que servem de fundamento ao dever de obediência ao soberano, amparam-se em princípios jurídicos, teológicos e biológicos. Tais princípios, entretanto, não dão conta da questão da extensão do poder soberano. Hobbes recorre à análise da linguagem. Sua teoria contratual afirma o princípio de preservação da vida na base da política e sustenta a ideia da criação e da manutenção do poder soberano no ato de linguagem implicado na estrutura representativa do pacto político.

- PALAVRAS-CHAVE: direito, direito natural, filosofia política, Hobbes, lei natural, liberdade, poder soberano.

Em conferência proferida em 1949 na Universidade de Chicago, publicada depois em coletânea de artigos com o título de Direito natural e história, Leo Strauss refere-se a um sentimento que temos, o terror sagrado da liberdade, tipo de pressentimento de que nem tudo é permitido ou, ainda em suas palavras, pressentimento do direito, que seria o freio natural da li-

1 Professora pesquisadora da Faculdade de Filosofia da Pontifícia Universidade Católica de Campinas (PUC-Camp). Artigo recebido em 11/2008 e aprovado em 06/2009. 
berdade humana. Não é fácil perceber que reflexão poderia orientar essas afirmações, que apareciam juntamente com a apologia do direito natural clássico e com a reafirmação da sociabilidade natural da espécie humana, já que se tratava de um pensamento em gestação nessa época marcada pelo signo da barbárie.

Quase dez anos depois, em 1958, portanto, ainda sob os efeitos do terror do século XX, outro autor célebre, Isaiah Berlin, ministra uma aula inaugural na Universidade de Oxford (publicada depois sob o título de Os dois conceitos de liberdade), com a convicção de que, para afrontarmos as mazelas das sociedades liberais contemporâneas - corporificadas na chaga totalitária -, temos de recorrer a dois modelos de liberdade: a liberdade-autonomia, que os filósofos modernos atribuíam à vontade humana, mas cuja realização requer condições especiais no âmbito político, e a liberdade concebida negativamente, isto é, a liberdade caracterizada como não interferência dos outros nas tentativas de realizar os desejos e a vontade, concepção negativa de liberdade também oriunda do pensamento moderno.

Essas duas concepções, segundo Berlin, tomaram rumos tão díspares, que se encontram irreconciliáveis. Há em seu texto uma crítica perversa à concepção positiva de liberdade. Tal concepção - que poderia, aliás, ser retomada com base em uma análise da obra de Rousseau - não responde, segundo ele, à pergunta sobre o espaço que se requer para que a pessoa faça o que pode fazer. Ela estaria, antes, voltada à questão da fonte do poder ou da instância de controle apta a determinar o que as pessoas podem fazer. Ao formular-se tal concepção de liberdade como atributo da vontade, liberdade-autonomia, o que estaria em jogo não seria perguntar que extensão deve ter o poder político para que o indivíduo possa exercer sua liberdade. Cumpre, antes, buscar a justificação desse poder, formulando-se a questão de sua origem.

Questão, aliás, a que as teorias contratuais modernas tentavam efetivamente responder. É possível que I. Berlin tenha razão quanto à existência dessas duas concepções de liberdade. Mas, se hoje estamos diante de dois modelos irreconciliáveis de liberdade, um que enfatiza a aderência e fidelidade a si mesmo, que podemos atribuir a Rousseau, e outro que, supondo algumas concepções análogas às da antropologia de Hobbes, ${ }^{2}$ vê o exercício

2 Além das concepções a respeito da origem, da extensão e da natureza do poder político, chamamos atenção para a análise da natureza humana, com base na qual Hobbes formula suas concepções da lei natural e do dever político. Não há unanimidade nas interpretações de sua obra política a respeito da associação entre as concepções jurídicas e a análise da natureza humana. Por exemplo, para Howard Warrender (1957), que considera não ser o dever político deduzido da natureza humana, mas da vontade ou autoridade de Deus, discussão retomada por Stuart M. Brown Jr. (1959) e por C. B. Macpherson (1979). 
dos direitos naturais apenas como resultado das lacunas do poder coercitivo, como explicar essa oposição teórica que tornaria as duas concepções irreconciliáveis? Estaríamos diante de duas teorias incongruentes? Como pensar tal incongruência diante das obras de Hobbes e de Rousseau, respectivamente, expressão inaugural e expressão final do contratualismo moderno?

Na linguagem jurídica que encontramos nos textos modernos, perguntava-se pela possibilidade de existência dos direitos naturais e punha-se na base dos valores morais a vontade humana, a razão e a consciência. Nesse sentido, as reflexões modernas sobre os direitos individuais são marcadas pela afirmação do aspecto subjetivo desses direitos. Como é que passamos dessas considerações abstratas, decorrentes de um conceito geral de natureza humana, para o exame das práticas políticas e sociais, acabando por formular a questão da possibilidade do convívio entre indivíduos e povos diferentes sem cair na tentação relativista gerada, segundo L. Strauss, pela destruição dos padrões éticos objetivos no decorrer da formação da filosofia jurídica moderna?

Ora, apesar de a filosofia política moderna ser fortemente marcada pelo pensamento jurídico, chegando por vezes a confundir-se com este, é possível localizar na obra de Hobbes o momento em que a política separa-se do direito, já que este não se ampara mais na natureza, passando a ser considerado como criação humana, artifício da razão. O estatuto mesmo do direito, isto é, aquilo que confere juridicidade a algo, deixa de se referir a uma finalidade inerente à natureza para tornar-se efeito das ações humanas. Esta é a nossa hipótese: ao pensar o direito como obra humana, nosso autor não abandona, contudo, a investigação acerca dos padrões objetivos de nossos juízos éticos. Ele mantém no horizonte do direito as ideias de lei natural e de direito natural. Assim, a despeito de ele abrir as vias para o relativismo, como pretende L. Strauss ao se referir a Hobbes, a ênfase conferida à história e à ação humana, à prática discursiva e à experiência política não nos permite afirmar que, de sua obra política, decorra uma negação da necessidade de buscar padrões morais, jurídicos e políticos que independam das decisões arbitrárias do soberano. Tal é o que nos permite pensar a análise de sua concepção de liberdade e de direito natural.

A obra de Hobbes é um marco na história da filosofia política, deixando-nos, nesse sentido, um legado comparável ao de Maquiavel. Se este é responsável pelo divórcio entre pensamento político e pensamento moral, o outro introduz uma fratura no alicerce construído por uma longa tradição que costumava associar a questão da natureza do poder político à de sua legitimidade. Entre o político e o jurídico estabelece-se, ao mesmo tempo, conjunção e ruptura. Conjunção porque na ótica de Hobbes não é possível pensar as ideias do dever político, do Soberano e do Estado (commonwealth) sem uma referência prévia às ideias do estado de natureza, com suas concepções das leis naturais e do direito natural, e também porque, como já 
ocorria anteriormente, o poder soberano é pensado com base em uma indagação acerca de sua legitimidade. Ruptura porque, ao tentar-se responder à questão das origens do poder político, o eixo que o associa à questão da legitimidade é deslocado: a primeira fonte de juridicidade não é mais Deus ou a natureza, mas o homem, a natureza humana.

À luz das discussões contemporâneas acerca das origens do totalitarismo e da análise do conceito moderno de liberdade, retomamos alguns pontos do pensamento de Hobbes, não propriamente com o intuito de decidir sobre a influência desse filósofo na formação de um pensamento favorável à atitude totalitária, mas para buscarmos parâmetros que orientem na interpretação dos textos modernos no que tange à problemática concernente à relação entre plano ético, plano político e plano jurídico. Com efeito, o presente estudo faz parte de uma pesquisa mais ampla, sobre as relações estabelecidas na modernidade entre as concepções dos direitos naturais, dos direitos políticos e dos direitos humanos, sobre a extensão do poder político no âmbito das questões relativas aos direitos individuais e sobre as repercussões teóricas que os conceitos modernos relacionados aos direitos subjetivos (liberdade, vontade, sentimento moral) têm sobre o pensamento contemporâneo. Trata-se de uma investigação teórica que visa a situar o papel da filosofia moderna na construção dos ideais contemporâneos de direito e de democracia.

Liberdade, no entender de Hobbes, é ausência de obstáculos externos às ações que contribuem para a preservação da vida. Como notamos no Capítulo 14 do Leviatã, a liberdade é um direito, e opõe-se à lei e à obrigação. Estamos diante de um direito originário, condição humana, mas aqui a tônica recai mais sobre os apetites e desejos do que sobre alguma qualidade intrínseca específica do homem. Nesse sentido, destoa sua concepção de liberdade daquela que encontramos no Discurso sobre a desigualdade, de Rousseau, liberdade como dom essencial da natureza, elemento distintivo da natureza humana, poder de querer e escolher caracterizado como uma ação puramente espiritual.

Se para o filósofo genebrino esse ato espiritual atribui-se à vontade e é opaco às leis da mecânica, para o de Malmesbury no contexto da escolha não cabe falar em liberdade. Atribuir liberdade à vontade é, nesse sentido, um absurdo. Podemos notar que Hobbes e Rousseau sustentam, então, concepções opostas de liberdade. ${ }^{3}$ Em seu texto de 1654, Da liberdade e da ne-

3 Em trabalho anterior examinamos a oposição entre o pensamento de Rousseau e o de C.-A. Helvétius, notadamente no que concerne à liberdade, à natureza humana e aos princípios da moral e da política (Maruyama, 2005). 
cessidade, Hobbes discute com o Marquês de Newcastle, John Bramhal, para quem se trataria de saber se o princípio da vontade é interior ou não: se tenho vontade de falar, andar ou escrever, devo indagar-me se essa vontade pertence a mim efetivamente ou não, se ela está inscrita em algo que me pertence, que está em meu poder ou não. Mas, pensa nosso filósofo, a afirmação do tipo posso querer se eu quiser não tem sentido. Atribuir liberdade à vontade nos leva a uma concepção ilusória, como se houvesse em nós algo sobre o qual pudéssemos dizer que é incausado, incondicionado, como se possuíssemos as causas últimas de nossa vontade.

Não vem ao caso aqui compreender plenamente o que Rousseau considerava como "vontade", um poder do homem que, além de distingui-lo dos outros animais, parece associar-se à alma, e não ao corpo. ${ }^{4}$ Por outro lado, é fato que, para Hobbes, a natureza da escolha depende de uma cadeia de paixões, cujo princípio é material, já que, enquanto movimento voluntário, ampara-se na imaginação, um tipo de sensação e, portanto, oriunda do contato dos objetos externos com os órgãos dos sentidos. A vontade, um apetite que precede à ação derivada de uma deliberação, nada mais é do que um movimento provocado, em última instância, pelas causas materiais, corpóreas, chamadas de causas naturais. ${ }^{5}$ Não é difícil compreender por que, para esse filósofo, liberdade envolve necessidade, aplicando-se à ação, e não a alguma qualidade intrínseca ao espírito. ${ }^{6}$

De qualquer modo, para ele, todas as nossas escolhas e deliberações são necessitadas. Há uma concatenação de causas determinando nossas paixões, desejos e apetites. "Posso fazer se quiser", isso é liberdade. Atribuir liberdade à vontade é um absurdo. No Capítulo 21 do Leviatã, encontramos o mesmo tipo de consideração: do uso da expressão "livre arbítrio" (free will) não podemos inferir nenhuma liberdade da vontade, do desejo ou da inclinação. Só podemos referir-nos àquela liberdade do homem que é atribuída a suas ações, e não a sua vontade.

4 Tal como vemos no Discours sur l'origine de l'inégalité parmi les hommes (Rousseau, 1964, v. 3, p. 141-2). A liberdade considerada como um ato ou uma espécie de qualidade que se atribui à alma humana, em contraposição às qualidades corpóreas, aparece também em sua obra Émíle ou de l'éducation, na qual encontramos, todavia, uma concepção um pouco diferente de vontade. A caracterização da vontade como poder de escolher não aparece nessa obra. Ver Émile (Rousseau, 1969 , v. 4, p. 586)

5 Cf. os seis primeiros capítulos do Leviathan or the Matter, Form and Power of a Commonwealth Ecclesiastical and Civil (Hobbes, 1843) e Elements of Philosophy (Hobbes, 1839, v. 1, cap. 25). Nas referências à obra Leviatã, adotarei sempre essa edição de 1843, indicando entre parênteses no corpo do texto o título da obra.

6 Of Liberty and Necessity: a Treatise wherein all Controversy concerning Predestination, Election, Free-Will, Grace, Merits, Reprobation etc. Is Fully Decided and Cleared (Hobbes, 1839, v. 4) 
A liberdade, para Hobbes, é um direito que temos de agir em conformidade com nossos desejos, vontades e inclinações. Já que nesse contexto liberdade não é um termo que se aplique para designar algum ato propriamente espiritual, e sim para caracterizar a ação humana possível na ausência de entraves externos, podemos dizer que essa concepção de liberdade é negativa. A liberdade enquanto direito natural é o fato mesmo de o homem, na ausência de algum poder exterior, não deparar com entraves ao fazer aquilo que tem vontade de fazer. Podemos, assim, situar o filósofo entre os defensores daquela que I. Berlin qualificava como liberdade negativa, ${ }^{7}$ mas é preciso notar que a questão central em sua obra política não era tanto a da extensão ou a da limitação do poder político, mas principalmente a da fundamentação da obediência que se deve ao Soberano.

Hobbes reúne duas tradições, a do humanismo renascentista que passa pelo realismo de Maquiavel com a dos teóricos da lei natural, incorporando a esta um novo modo de justificar e reforçar as leis civis e o poder político. ${ }^{8}$ Para L. Strauss, Hobbes é o fundador da doutrina moderna da lei natural, fazendo de um direito natural incondicional o fundamento de todos os deveres naturais. Não é preciso ressaltar que o direito natural exprime aspirações individuais. Poderíamos, todavia, amenizar a platitude com que todos os desejos e paixões são tratados no Leviatã, já que para o intérprete há uma base moral na obra política do filósofo, embora do ponto de vista da eficácia do direito natural ela seja dispensável (Strauss, 1963, cap. 5). É o que ele caracteriza como fundamento moral na obra desse filósofo, o conhecimento de si mesmo, mas vale ressaltar também o medo da morte violenta, segundo ele, único fundamento do dever. ${ }^{9}$ A ênfase recai no indivíduo, que tem primazia e independência em relação à sociedade civil. Para L. Strauss, a novidade aqui não reside na busca das origens da sociedade civil ou de uma suposta vida pré-política do homem, mas na assimilação desses elementos à concepção do estado de natureza, que Hobbes levaria da teologia cristã à filosofia política.

7 Para I. Berlin, o marco divisório entre os defensores da concepção negativa da liberdade e os que defendem a concepção da liberdade positiva constitui-se também pelo tratamento conferido ao poder político. Enquanto para os primeiros trata-se de examinar a questão da extensão e dos limites do poder, para os últimos cabe indagar a respeito das condições para a realização da liberdade com base na discussão sobre a origem do poder.

8 Sobre as influências no pensamento político de Hobbes, cf. Strauss (1963), Skinner (1996), Pocock (1981). Esses dois últimos autores mantêm, ainda, uma discussão sobre o método empregado na história da filosofia política.

9 O conhecimento ou a consciência de si mesmo não é conhecimento da essência do homem (ponto de vista universal), mas de sua relação com outros indivíduos, de sua situação em face dos outros (ponto de vista particular). Ver Strauss, 1963, mais particularmente os caps. 2 e 7. 
Não há, contudo, uma base moral que possa despregar-se do plano da matéria. Cálculo da razão, imaginação, direito natural: não importa de que modo possamos caracterizar essa dimensão subjetiva em sua obra política, é sempre preciso fazer referência, em última instância, ao corpóreo. A referência ao corpo na concepção hobbesiana da liberdade natural é clara. Aplicar o termo "liberdade" a algo que não seja corpo é abuso de linguagem (Hobbes, 1843, Leviathan, cap. 21). Dizer que um homem é livre não implica tomá-lo como alguma essência independente do corpo.

De acordo com Hobbes, o direito natural, ou liberdade, é algo que cada ser possui em função de uma espécie de princípio de conservação. O que parece confirmar a tese de B. Barret-Kriegel (1989), que chama atenção para as más interpretações do pensamento jurídico moderno que desvinculam a concepção do direito natural de sua base biológica. O direito natural e, por consequência, o próprio direito (pois, em certo sentido, este seria uma parte daquele, já que não há nada mais primário do que o jus naturale) estão vinculados à conservação da vida, princípio biológico. Não há como separarmos totalmente aqui plano jurídico e plano biológico.

Apesar de poder ser associado a um princípio negativo, como vimos, o direito natural é, por assim dizer, positivado pelas leis naturais. Em si mesmo, o direito natural não é dado real, coisa ou substância, nem é essência, mas caracteriza-se como liberdade de usar o próprio poder para a preservação da vida. É como se houvesse um vácuo jurídico, situação em que tudo é permitido - "em tal condição todo homem tem direito a todas as coisas, incluindo os corpos dos outros" (Hobbes, 1843, Leviathan, cap. 14). Mas, se supomos essa ausência de impedimentos externos à realização do direito natural, situação de pura liberdade, que se confundiria com a própria condição natural do homem, a da guerra de todos contra todos, como seria possível pensar a preservação da espécie humana?

Com efeito, a concepção do estado de natureza de Hobbes exige a suposição das leis naturais. Embora seja preciso acatar as indicações do filósofo, e distinguir lex e jus, lei e direito, este não existe fora do horizonte das leis. No Capítulo 14 do De Cive, Hobbes notava que, se removemos as leis, nossa liberdade é absoluta. A liberdade, ainda que de modo negativo, não se pensa sem as leis. As leis não constituem o direito natural, embora o sancionem, de algum modo, portanto, aprovando-o. O direito natural aqui aparece como elemento residual, o que não foi proibido pelas leis. Se não é proibido, permite-se. A oposição entre lei e direito supõe uma ordenação, embora, como mostra essa passagem do De Cive, não seja totalmente impensável uma situação em que nada é proibido, isto é, um momento de liberdade absoluta.

Curiosamente, no texto desse autor, nem o estado de natureza admite tal liberdade. As leis naturais - que são leis morais e leis divinas - obrigam, 
ainda que apenas in foro interno. Temos, então, na concepção do estado de natureza de Hobbes, uma interiorização de todo o aparato jurídico de sanção-proibição-ordenação. Se transportamos à filosofia política alguns princípios da teologia cristã, como quer L. Strauss, ou se fundamos o dever político na obrigação diante das leis, da vontade e da autoridade divina, não é digno de esquecimento que toda essa dimensão subjetiva (direito, liberdade, consciência) acaba sendo legada àquele que detém o poder soberano. Legada, mas, como veremos, não postergada.

Seja como for, do ponto de vista da natureza, não há nada que sirva como obstáculo quando se trata da autoconservação. O que equivale a dizer: não há juridicidade propriamente falando no estado de natureza, em que rege a força bruta. Hobbes admite que a força pode dar origem a um direito, mas não que este possa ser constituído com base naquela. É possível pensarmos na situação de conquista, formação do Estado por aquisição, em que um povo submete outro a seu poder pela força. Nesse caso, todavia, o que caracteriza e constitui o dever de obediência não é a força, mas o acordo estabelecido, o pacto celebrado (Hobbes, 1843, Leviathan, cap. 20). ${ }^{10}$ Uma relação de força ou poder entre indivíduos numa situação em que não há legalidade positiva não gera, por si mesma, um direito, embora leve ao acordo, ao pacto político enquanto renúncia à autoridade individual. Na condição natural da humanidade, cada indivíduo tem direito a tudo o que contribua para sua conservação e bem-estar, e ele acredita ter esse direito. A renúncia que um homem faz de seu direito, renúncia implicada no pacto instaurador do poder político, é deixar de pretender negar ao outro esse mesmo direito; em outras palavras, é reconhecer que todos os outros têm também um direito sobre as mesmas coisas que ele próprio. ${ }^{11}$ Só assim é possível acordo, justiça, partilha.

No De Cive, Hobbes insiste mais a esse respeito, embora não sem gerar certo embaraço em relação à sua concepção de liberdade. No Capítulo 5 dessa obra, nota-se que a convergência das várias vontades particulares

10 Se, na condição natural da humanidade, todo indivíduo tem direito a todas as coisas, podemos dizer que todo indivíduo tem o direito de reinar sobre todos os demais. Ora, pensa Hobbes, esse direito não pode ser obtido pela força, mas requer o acordo, já que não há nenhum indivíduo com poder irresistível, o qual pertence apenas a Deus todo-poderoso (cf. Hobbes, 1843, Leviathan, cap. 31).

11 “To lay down a man's right to any thing, is to divest himself of the liberty, of hindering another of the benefit of his own right to the same. For he that renounceth, or passeth away his right, giveth not to any other man a right which he had not before; because there is nothing to which every man had not right by nature: but only standeth out of his way, that he may enjoy his own original right, without hindrance from him; not without hindrance from another. So that the effect which redoundeth to one man, by another man's defect of right, is but so much diminution of impediments to the use of his own right original" (Hobbes, 1843, Leviathan, cap. 14). 
em direção a um fim comum não é suficiente para o estabelecimento da paz e conservação entre os homens. É preciso que haja uma única vontade para todos os homens, o que não deixa de prenunciar a concepção da vontade geral do Contrato social de Rousseau. O problema é que a união que cria essa vontade comum, no entender de Hobbes, tal como notamos nesse texto, é a submissão das vontades individuais à vontade de alguém ou de um conselho, o que o distingue de Rousseau, que não aceita a ideia da representação, como se um ser individual pudesse representar a vontade geral, do corpo político. Mas se, como vemos no Leviatã, a vontade é apenas uma paixão que precede imediatamente a ação deliberada, portanto, apenas ato ou movimento, e não propriamente uma qualidade inerente ao homem não estão em nós as causas de nossa vontade -, como poderíamos submetêla a algo? Vale aqui a pergunta: como alienar algo que não possuímos? É o que o filósofo de Malmesbury tenta explicar logo em seguida. Embora não seja rigoroso dizer que a vontade é livre, já que ela é apenas início das ações voluntárias, quem submete sua vontade à de outrem nada mais faz, nas palavras do De Cive, do que conferir a este o direito à sua força e às suas faculdades (Hobbes, 1843, De Cive, cap. 5, §§ 6-8). ${ }^{12}$

No Leviatã o autor é mais direto, deixando de lado os detalhes da discussão, quando, no Capítulo 17, apresenta o pacto político em termos de transferência de força e poder ou quando desenvolve, no Capítulo 16, sua teoria da representação para tratar dos pactos em termos de transferência de autoridade, isto é, do direito de cometer uma ação. Vale, todavia, a conclusão a respeito das leis naturais (justiça, equidade, modéstia, piedade), que seriam contrárias a nossas paixões na ausência do temor de algum poder capaz de levá-las a serem respeitadas. As paixões tendem à parcialidade, à vaidade, ao orgulho, é preciso, portanto, controlá-las. ${ }^{13}$ Sem um po-

12 Na edição inglesa desta obra De Cive, de 1651, que é retomada nesta, de Malesworth, a capa apresenta o seguinte título e explicações: "Philosophical Rudiments concerning government and society or, a dissertation concerning man in his several habitudes and respects, as the member of a society, first secular, and then sacred. Containing the elements of civil politie in the agreement which it hath both with natural and divine laws. In which it is demonstrated, both what the origin of justice is, and wherein the essence of Christian Religion doth consist. Together with the nature, limits, and qualification both of regiment and subjection".

13 Esta questão é, de certo modo, divisória: Rousseau distingue claramente amor de si e amor próprio, no Discurso sobre a desigualdade, provavelmente para marcar seu desacordo com Hobbes e outros de sua época que conferem às ações e às paixões humanas uma tendência egoísta. Não obstante, no Contrato social, ele também parte do princípio de que o indivíduo tende à satisfação de seus interesses particulares, mantendo sua vontade em oposição à vontade geral. Se não houvesse oposição entre vontade geral e vontade particular, o pacto político seria desnecessário. Sobre essa crítica de Rousseau a Hobbes remeto-os ao livro de Robert Dérathé (1950). Traduzi para o português essa obra, referência obrigatória para os estudos da filosofia política de Rousseau, que será publicada em breve. 
der político forte, as paixões humanas opõem-se às leis naturais. Daí a necessidade da instauração do poder político soberano e, nos casos de domínio pela guerra, da justificação desse tipo de poder. Como nota JeanFabien Spitz (1995, p. 38), na história do pensamento liberal não há incompatibilidade entre o egoísmo dos indivíduos e a autoridade soberana forte. ${ }^{14}$

O momento do pacto político, em que se transfere autoridade, força e poder a um ou a vários homens que representarão a vontade da comunidade, coincide com o momento de criação do direito propriamente dito. Aquele direito natural, pré-existente ao pacto, não pode ser caracterizado como qualidade de um sujeito tomado em suas dimensões jurídicas ou em suas relações com os outros (Hobbes, 1843, Leviathan, cap. 14). Nesse sentido, o direito natural é sempre negativo. Reconhecer esse direito aos outros é, de certo modo, renunciar a ele. Do conteúdo das leis naturais decorrem os elementos que compõem a teoria da representação. Não poderíamos manter uma existência enquanto proprietários sem sermos, ao mesmo tempo, autores, portanto, sem estabelecermos de algum modo uma relação de representação. Não é possível pensar o direito sem se mencionar o ato de representação implicado no pacto político. Mas o que seria esse ato de representação e que estatuto se pode conferir ao pacto político nos textos de Hobbes?

No Capítulo 16 do Leviatã, uma das passagens mais importantes dessa obra, Hobbes traz a fundamentação jurídica de sua concepção do pacto político, deixando-nos entrever o nexo entre direito e política. Além de não haver algo que possamos chamar de propriedade na condição natural da humanidade, a relação entre autor e ator, compreendida na transferência de autoridade pelo pacto, é pressuposição necessária para a caracterização do campo jurídico e político. Hobbes sugere que toda ação é representação. ${ }^{15}$ Há uma distinção entre a pessoa natural e a pessoa fictícia ou artificial, e importa mais a segunda, pois o conceito de pessoa fictícia expõe mais claramente a relação de personificação. Personificar é representar, nota Hobbes, estabelecendo-se sempre, portanto, uma relação entre o autor, aquele a quem pertencem de direito as ações, e o ator que as representa - notemos também que é possível representar os outros ou a si mesmo.

Nesse mesmo registro, o da criação de um direito pelo pacto político, encontramos uma passagem significativa do Capítulo 10 do Leviatã, em que o merecimento é distinguido do valor e do mérito. O merecimento é a habilidade particular de alguém para algo de que se diz que ele é merecedor,

$14 \mathrm{Na}$ obra de Hobbes expressa-se a percepção das contradições do individualismo moderno. Sobre essa questão, ver Vaughan (1960).

15 Sobre essa questão, ver Pitkin (1967), mais especificamente o capítulo intitulado "The Problem of Thomas Hobbes". 
nesse sentido, é adequação ou aptidão. É possível, contudo, ser merecedor - ter merecimento, isto é, ter uma habilidade particular para algo de que se diz que ele é merecedor - sem merecer, no sentido do mérito, que pressupõe um direito ou um merecimento oriundo de alguma promessa. Nesse caso, não se pode dizer que haja realmente merecimento, pois o mérito supõe direito, e o direito supõe promessa ou contrato. Para pensarmos as concepções de direito e de direito natural, na obra política de Hobbes, é sempre preciso considerar a oposição natureza e artifício, tema que caracterizará, aliás, todas as teorias contratuais.

O termo "direito" atribui-se primeiramente aos indivíduos quando estes são considerados em sua condição natural, isto é, sem as leis civis, sem a comunidade política ou o poder comum. Seja compreendido como direito a todas as coisas ou como liberdade natural, o direito individual aparece como elemento perturbador, e é preciso renunciar a ele. Todos têm mesmo direito e mesma força, e essa igualdade gera a guerra generalizada. Tal renúncia, entretanto, não implica verdadeiro abandono do direito, mas reconhecimento do mesmo direito aos outros. Diante de uma situação em que se trata de conservar a própria vida, de manter a segurança e o bem-estar, não pode haver verdadeira renúncia dos direitos, pois existe uma obrigação natural em relação à própria vida (Hobbes, 1843, Leviathan, cap. 14). ${ }^{16}$

Por outro lado, no que se refere à multidão, como podemos notar no Capítulo 6 do De Cive, ela só tem algum direito se supomos a existência da sociedade civil, o que equivale a dizer que, do ponto de vista da comunidade política, somente a verdadeira união permite falar em direito. Em outros termos, se para o filósofo os direitos individuais são originários, os direitos coletivos subsumem-se ao pacto de associação. Não há direito reservado às hordas. O ser coletivo, para Hobbes, é muitos. Do ponto de vista da natureza (e de Deus), só há direitos individuais. Não se reconhecem, então, os direitos dos povos por eles mesmos, mas somente na medida em que estes participam de uma verdadeira associação, com um poder comum, soberano, e uma vontade única na pessoa que detém o poder político. ${ }^{17}$

As concepções do estado de natureza e das leis naturais exercem uma função de anteparo dos direitos originários, expressão hobbesiana do desvelo humano pela própria vida. Assim, mais do que servir à justificação do

16 Há obrigação natural do indivíduo não apenas em relação à preservação da própria vida, mas no que concerne à busca dos meios para tornar a vida tal que dela ele não se canse. O compromisso com a vida é anterior ao medo da morte violenta. L. Foisneau (2000) nota que essa obrigação natural sustenta-se no poder divino.

17 Como podemos notar no Capítulo 30 do Leviatã, o direito dos povos é direito do soberano, e não do corpo do povo; estamos aqui diante de um direito individual - embora, como veremos, de tipo distinto, quando comparado à liberdade negativa -, e não diante de um direito coletivo. 
poder soberano absoluto - tem-se frequentemente insistido nisso -, a construção teórica do estado de natureza auxilia na caracterização dos direitos individuais. Em seu substrato traz algo de originário, tanto no âmbito da lei como no da liberdade, ainda que sempre se referindo ao corpóreo e ao biológico. Do ponto de vista de Hobbes, transferimos um direito apenas em consideração a outro direito ou a algum outro bem com o qual o trocamos, pois estamos diante de um ato voluntário, e o objetivo de todos os atos voluntários é obter algum bem para si mesmo. Sendo o maior bem a própria vida, ninguém renuncia ao direito de resistir a algo que ameace sua vida ou que lhe cause um sofrimento corporal (Hobbes, 1843, Leviathan, caps. 14 e 21).

Mas será que o termo "direito" quando referido aos direitos naturais e o termo "direito" em referência aos direitos do soberano têm o mesmo sentido? Há aqui univocidade? Para J. Plamenatz, a própria concepção do direito natural em Hobbes é obscura. Segundo ele, o sentido conferido ao termo "direito natural" para descrever a condição primitiva da humanidade é diferente do sentido que o filósofo emprega para explicar a autoridade soberana legítima e absoluta. O direito do soberano, o qual tem seu poder fundado na ideia do pacto político, possui um estatuto distinto daquele do direito natural, "jus naturale" (Hobbes, 1843, Leviathan, cap. 14), a começar pelo fato de que o primeiro concerne ao corpo político, a commonwealth, enquanto o segundo é um direito individual. O soberano recebe dos indivíduos contratantes, por transferência, os direitos naturais, a começar pela autoridade, o direito de agir. Ele deve responder às causas que o produziram, enquanto representante dos indivíduos que contratam. É de se notar, entretanto, que, como representante de cada súdito, o qual conferiu, renunciou e transferiu seu direito ao poder comum, o soberano pode tudo: é ele quem cria os padrões para distinguirmos o bem do mal, o justo do injusto.

Há uma diferença de estatuto entre o direito natural, individual, e o direito do soberano, a qual diz respeito à comunidade: o primeiro é natural, podemos dizer também originário, ao passo que o segundo é obra humana, artifício da razão, resultado do pacto. Do ponto de vista da natureza, o soberano, "súdito de Deus" (Hobbes, 1843, Leviathan, cap. 21), ${ }^{18}$ é obrigado a respeitar as leis da natureza. Nesse sentido, ele não poderia atentar contra a vida de um indivíduo. Do ponto de vista do direito positivo, entretanto, ele tem poder de vida e de morte sobre seus súditos, nada do que ele faça pode ser dito injusto, a ele nunca falta o direito a seja lá o que for.

18 Quando o soberano erra, condenando, por exemplo, um inocente, não o faz perante seus súditos, mas perante as leis de natureza, perante Deus. Estamos diante de uma injúria a Deus, e não ao inocente julgado erroneamente pelo soberano. 
O soberano, como súdito de Deus, deve-lhe obediência. Quanto às regras e determinações das ações no âmbito da commonwealth, todavia, é ele quem decide o que é lícito ou não fazer; ele é a autoridade máxima na comunidade política. Nesse sentido, os indivíduos devem obediência ao soberano não apenas porque este tem a espada, a força pública, mas também porque é razoável obedecer-lhe, já que sua autoridade recebe de Hobbes uma justificação teórica, racional, com a teoria do pacto político. Mesmo quando se ressalta a importância da ideia do poder divino em sua obra, é preciso notar que, para Hobbes, a obediência às leis da natureza ou aos mandamentos divinos não pode servir de justificativa para a desobediência civil. Luc Foisneau (2000) nota que ninguém poderia apelar para um engajamento individual em relação a Deus para subtrair-se a suas obrigações em relação ao Estado. O modo pelo qual o filósofo pensa o poder divino, reconhece o intérprete, sustenta-se, contudo, pela ideia da obrigação natural, que, por sua vez, decorre da suposição a respeito da soberania absoluta de Deus sobre a vida humana.

Para Hobbes, do ponto de vista do direito civil e político, cabe somente ao soberano decidir e julgar. Assim, a liberdade é caracterizada como qualidade que se atribui à ação, e não à vontade, e que reside apenas naquelas coisas que, ao regular suas ações, o soberano permitiu (Hobbes, 1843, Leviathan, cap. 21). O direito de natureza, liberdade natural do homem, pode, então, ser legitimamente limitado pelas leis da comunidade política. A finalidade da lei é essa restrição, sem a qual, de certo modo, não haveria paz. No Capítulo 26, sobre a lei civil, no Leviatã, Hobbes é enfático: a lei foi trazida ao mundo para limitar a liberdade natural dos indivíduos.

Mas a lei civil em Hobbes, ainda que pertença à jurisdição do poder político soberano, coincide, de certo modo, em seu princípio, com a lei natural. É por isso que podemos confiar nas decisões do soberano em sua interpretação das leis naturais; essas leis fazem parte da razão natural. Referimonos aqui às leis naturais como fonte de juridicidade, e elas estão também compreendidas nas leis civis, pois o fundamento destas reside no pacto político. Ora, de que modo o pacto é fundamento das leis civis? Não apenas porque ele está na origem lógica da formação da comunidade política, do poder soberano e, por conseguinte, da lei civil, mas porque ele expressa instruções da razão natural, instruções que podem ser chamadas em seu conjunto de fidelidade (Hobbes, 1843, Leviathan, cap. 26). Nós temos necessidade do Estado para interpretar as leis de natureza, de modo que convém tratar a lei de natureza como parte da lei civil. Isso não implica, entretanto, que, variando sua interpretação de um estado particular para outro, de um povo a outro, varie também seu estatuto. A lei de natureza nunca é relativizada nos textos de Hobbes. A lei de natureza é considerada como parte da lei civil no sentido de que tem de ser interpretada, e é mais confiável que o 
seja, pela autoridade soberana, mas ela é também considerada pelo autor como lei eterna e divina. ${ }^{19}$

Como nota Plamenatz, em seu Man and Society, as leis de natureza são leis de Deus, e os direitos naturais, embora possam ser assegurados pelos governos, não são criados por estes. Temos um dever diante de Deus, e o soberano também. Só devemos obediência a este último enquanto ele mantém as cláusulas do contrato, isto é, só posso manter minha obediência para com o soberano se, de fato, essa obediência é um meio de cumprir minha obediência para com Deus. Segundo Plamenatz, temos base para acreditar que, aos olhos de Hobbes, obedecendo ao soberano, estamos obedecendo a Deus, pois Deus ordena que ajamos prudentemente para nossa conservaÇão, e só podemos agir assim se não resistimos ao soberano, exceto nos casos em que ele ameace destruir nossa vida ou prender-nos.

Se não existisse dever de obedecer a Deus, ninguém no estado de natureza poderia impor-se qualquer tipo de dever, nem mesmo em relação ao cumprimento dos acordos, que é conteúdo da lei natural. Por outro lado, é apenas no contexto em que existe um poder soberano que podemos falar em dever de manter os acordos estabelecidos. Estamos, pois, aqui, naquele terreno em que lei civil e lei natural coincidem.

Quanto à concepção do direito natural, Plamenatz, em seu capítulo sobre Hobbes, aponta três sentidos desse termo na obra do filósofo. Primeiramente, temos o direito natural como liberdade, ausência de impedimentos, que, segundo Plamenatz, é o menos importante. Em segundo, o direito natural como ausência de obrigação, momento lógico que antecede o pacto político. Por fim, o mais importante deles, sentido do direito natural que cria ou que implica um dever para outrem. Trata-se aqui de uma consequência do pacto político, da relação de representação, a partir de que os súditos passam a dever obediência ao soberano.

É nesse último sentido que pensaríamos os direitos do soberano na obra política de Hobbes, direitos que limitam a liberdade natural e que implicam os deveres de seus súditos. ${ }^{20}$ Mas, entre o direito natural individual, que é a liberdade concebida negativamente, e o direito do soberano, que tem poder de vida e de morte sobre seus súditos, resguardam-se ainda outros dois sentidos do termo "direito natural" em sua obra: o direito natural que fora transferido pelo pacto ao soberano, mas que originariamente pertence ao indivíduo - direito de agir em causa própria, autoridade -, e aquele

19 A natureza da lei, pensa Hobbes, reside em sua intenção, na interpretação que dela se faz, segundo aquilo que o legislador quis dizer.

20 No Capítulo 30 do Leviatã, Hobbes chega a dizer que os direitos da soberania são leis naturais e fundamentais. 
direito natural que deriva do poder irresistível. Passando pelas ideias de pacto político e de representação, nosso filósofo desloca a questão da fundamentação do poder soberano absoluto, conduzindo a concepção do direito natural da esfera da liberdade natural ao princípio do poder puro e irresistível, onipotência e excelência de poder, direito de fazer sofrer.

A concepção de liberdade como direito natural, na obra de Hobbes, completa-se com a justificação do dever de obediência ao soberano e, concomitantemente, com a dedução das leis naturais. Nosso problema consistia, então, em indagar se, para Hobbes, o soberano, como "súdito de Deus", deve também obediência às leis de natureza, e nossas constatações apontavam para uma resposta positiva. Na medida em que participam de uma racionalidade inerente à política - racionalidade implicada na própria estrutura representativa do pacto político - tanto os súditos quanto o soberano devem obediência às leis de Deus. Como nota o próprio autor, as leis da natureza são leis morais, regras ou preceitos da razão, e expressam fundamentalmente um princípio de vida, amparadas que são logicamente na primeira lei da natureza, que concerne à autoconservação.

Ressaltamos a importância da concepção negativa da liberdade, assim como a das leis da natureza, tal como encontramos nos textos de Hobbes, para a elaboração de sua concepção do poder político. O poder soberano decorre do acordo estabelecido entre os indivíduos, pelo qual transferem o direito sobre as próprias ações a um poder comum que os representa. Para além da estrutura do pacto político, tais concepções acerca da liberdade e da lei natural apontam também para a ideia do poder irresistível e para a relação desse tipo de poder com o princípio de conservação da vida. Sua analogia com a caracterização do poder político soberano dá-se pelas ideias do direito natural e do dever natural. Deve-se obediência ao soberano porque tal dever contribui para a afirmação da vida, e esse dever é justificado apenas na medida em que o soberano atende essa necessidade da natureza humana.

É de se notar, todavia, que estamos aqui diante de um dever que é um dever político. Trata-se de uma obediência que se deve ao soberano na medida em que ele representa os indivíduos contratantes. Esse ato de representação é o núcleo mesmo do acordo que cria a comunidade política e o poder comum. Ele está também alicerçado, entretanto, no dever natural que acompanha as leis da natureza. A partir desse jogo entre os preceitos da razão, regras da natureza, nosso filósofo chega à elaboração de sua teoria contratual. Nesse sentido também se pensa o poder soberano.

Obrigação e liberdade são incompatíveis, como vemos no Capítulo 14 do Leviatã, mas ambas compõem o ato de submissão implicado no pacto 
político. A ideia de um direito originário tem uma base teológica - trata-se do direito de natureza, pelo qual Deus reina sobre os homens (Hobbes, 1843, Leviathan, cap. 31) -, funda-se, portanto, na ideia do poder irresistível, onipotente. Esse pressuposto teológico não altera, todavia, a estrutura mesma da obrigação. Podemos justificar racionalmente o dever de obediência ao soberano com base nas ideias de Deus e da lei divina, mas nada modifica o fato de que toda obrigação é, para Hobbes, decorrência da ação humana. Hobbes pensa a política e o direito em termos contratuais, supondo também a ação e a prática discursiva. A ação humana está na base da política, mas não no sentido da justificação externa do dever de obediência, como ocorre com a ideia do poder irresistível de Deus; ela é constitutiva da experiência política enquanto tal - já que é ato de linguagem -, seja quando expressa uma promessa ou acordo explicitamente, pelas palavras proferidas ou escritas, seja quando se lê na intenção daquele que participa da vida pública, isto é, daquele que se submete ao poder soberano.

O poder político soberano, justificado pelas leis da natureza - e, portanto, pelo pressuposto teológico concernente à proteção da vida e à busca da paz -, vincula-se, do ponto de vista ontológico, à ideia da natureza humana, à prática discursiva, à análise das paixões. Tendo considerado essas várias faces da concepção de poder nos textos de Hobbes - seus aspectos lógicos, teológicos e antropológicos -, podemos concluir com um comentário acerca da chamada biopolítica. A construção teórica inerente ao pensamento jurídico-político moderno, que orienta M. Foucault em seus estudos acerca do biopoder, compreende as seguintes etapas conceituais: estado de natureza, pacto político, poder soberano. É, entretanto, no tema da liberdade, concebida por Hobbes como qualidade que se atribui à ação, e não à vontade, e que é eminentemente uma liberdade corpórea, que se vislumbram traços da atitude que caracteriza a biopolítica: redução do homem ao simples ser vivente, indivíduo concebido apenas como vida animal, corpo biológico, diante do qual se apagam na indistinção características tradicionalmente consideradas essenciais ao homem, concernentes à capacidade humana intelectual, espiritual e moral, ou à aspiração à vida contemplativa e social (Aristóteles), aos germes dos sentimentos morais e humanitários, aos princípios da sociabilidade humana (Pufendorf), sem falarmos na tradição do livre arbítrio que percorre toda a história da filosofia ou na ideia da liberdade inalienável que encontramos nos textos de Rousseau.

É insustentável, entretanto, a pretensão de associar os problemas implicados na atuação do poder totalitário contemporâneo às repercussões éticas e políticas da ideia do poder soberano que encontramos na obra de Hobbes. Aqui o poder político encontra sua limitação não apenas teoricamente, nas ideias do direito natural e da lei natural, mas na própria estrutura do pacto político que lhe dá origem, já que depende também, e continua- 
mente, da prática discursiva, da ação, dos atos de linguagem, das intenções dos autores que fazem parte da cena política. O tratamento concedido por Hobbes ao tema da liberdade contribui, entretanto, ainda assim, para pensarmos essa trama do poder que Foucault caracterizava como decorrência da modernidade biológica. Mas tal consequência não se dá tanto pelos aspectos negativos de sua concepção da liberdade - liberdade como ausência de obstáculos externos à ação -, e sim pelo que ela traz de mais positivo: liberdade como princípio biológico de preservação da vida.

MARUYAMA, Natalia. Freedom, natural law and natural right in Hobbes: threshold of law and politics in modernity. Trans/Form/Ação, São Paulo, v.32(2), 2009, p.45-62.

- ABSTRACT: Liberty and power are two subjects correlated along the history of the political modern philosophy. In the texts of Hobbes, the idea of liberty as absence of impediments to the actions helps us to think the duty of obedience to the sovereign power and the relations between politics and right. A situation of legal vacuum, in which everything is allowed, is, nevertheless, impossible, so that the solution of Hobbes consists in supporting the idea of the natural right like original individual right linked to the preservation of the life. His ideas of the natural right and of the natural law, which serve of basis to the duty of obedience to a sovereign, lean on legal, theological and biological principles. In spite of that, such principles do not surround the question of the extension of the sovereign power. Hobbes resorts to the analysis of the language. His contractual theory affirms the principle of preservation of the life on basis of the politics and supports the idea of the creation and of the maintenance of the sovereign power in the act of language implicated in the representative structure of the political covenant.

- KEYWORDS: Hobbes, liberty, natural law, natural right, political philosophy, right, sovereign power.

\section{Referências bibliográficas}

BARRET-KRIEGEL, B. Les droits de l'homme et le droit naturel. Paris: PUF, 1989.

BERLIN, I. Os dois conceitos de liberdade. In: BERLIN, I. Quatro ensaios sobre a liberdade. Brasília: Editora Universidade de Brasília, 1969.

BROWN Jr., S. M. Hobbes: the Taylor Thesis. Philosophical Review, lxviii, 3, julho de 1959.

DÉRATHÉ, R. Jean-Jacques Rousseau et la science politique de son temps. Paris: PUF, 1950.

FOISNEAU, L. Hobbes et la toute-puissance de Dieu. Paris: PUF, 2000 [Col. Fondements de la Politique]. 
FOUCAULT, M. História da sexualidade I: vontade de saber, 10. ed. Trad. de M. T. da C. Albuquerque e J. A. G. Albuquerque. Rio de Janeiro: Graal, 1988.

Em defesa da sociedade: curso no Collège de France (1975-1976). Trad. de M. E. Galvão. São Paulo: Martins Fontes, 2002.

HOBBES, T. The Collected Works of Thomas Hobbes. Ed. Molesworth. Londres: 1839 (reed. de G. A. J. Rogers. Londres: Routledge/Thoemmes, 1992.

The Collected works of Thomas Hobbes. Ed. Molesworth. Londres: 1843. [cotejada com a edição de 1651].

MACPHERSON, C. B. A teoria política do individualismo possessivo: de Hobbes a Locke. Trad. de N. Dantas. Rio de Janeiro: Paz e Terra, 1979.

MARUYAMA, N. A moral e a filosofia política de Helvétius: uma discussão com J.-J. Rousseau. São Paulo: Humanitas/Fapesp, 2005, 643 p.

PITKIN, H. F. The Concept of Representation. Berkeley (Cal.): University of California Press, 1967.

PLAMENATZ, J. Man and Society: a Critical Examination of Some Important Social and Political Theory from Machiavelli to Marx, 2 vs. Londres: Longmans, 1963.

POCOCK, J. G. A. Virtues, Rights and Manners. Political Theory, n. 9, 1981.

ROUSSEAU, J.-J. Euvres Complètes de Jean-Jacques Rousseau. 5 vs. Paris: Gallimard, 1964-1995 [Col. Bibliothèque de la Pléiade].

SKINNER, Q. Reason and Rhetoric in the Philosophy of Hobbes. Cambridge/Nova York: Cambridge University Press, 1996 [Ed. brasileira: trad. de V. Ribeiro. São Paulo: Unesp, 1999].

SPITZ, J.-F. La liberté politique: essai de généalogie conceptuelle. Paris: PUF, 1995.

STRAUSS, L. Natural Right and History. Chicago: University of Chicago Press, 1953.

The Political Philosophy of Hobbes: its Basis and its Genesis. Chicago: Chicago University Press/Phoenix, 1963.

VAUGHAN, C. E. Studies in the History of Political Philosophy before and after Rousseau. Nova York: Russell \& Russell, 1960.

WARRENDER, H. The Political Philosophy of Hobbes: his Theory of Obligation. Oxford: Clarendon, 1957. 